\title{
Overcoming multiple drug resistance mechanisms in medulloblastoma
}

Ramadhan T Othman ${ }^{1}$, loanna Kimishi', Tracey D Bradshaw², Lisa CD Storer ${ }^{1}$, Andrey Korshunov ${ }^{3}$, Stefan M Pfister ${ }^{4}$, Richard G Grundy ${ }^{1}$, lan D Kerr ${ }^{5}$ and Beth Coyle ${ }^{1 *}$

\begin{abstract}
Introduction: Medulloblastoma (MB) is the most common malignant paediatric brain tumour. Recurrence and progression of disease occurs in $15-20 \%$ of standard risk and $30-40 \%$ of high risk patients. We analysed whether circumvention of chemoresistance pathways (drug export, DNA repair and apoptotic inhibition) can restore chemotherapeutic efficacy in a panel of MB cell lines.
\end{abstract}

Results: We demonstrate, by immunohistochemistry in patient tissue microarrays, that $A B C B 1$ is expressed in $43 \%$ of tumours and is significantly associated with high-risk. We show that ABCB1, O6-methylguanine-DNA-methyltransferase (MGMT) and BCL2 family members are differentially expressed (by quantitative reverse transcription polymerase chain reaction, Western blotting and flow cytometry) in MB cell lines. Based on these findings, each pathway was then inhibited or circumvented and cell survival assessed using clonogenic assays. Inhibition of ABCB1 using vardenafil or verapamil resulted in a significant increase in sensitivity to etoposide in ABCB1-expressing MB cell lines. Sensitivity to temozolomide (TMZ) was MGMT-dependent, but two novel imidazotetrazine derivatives ( $\mathrm{N}-3$ sulfoxide and N-3 propargyl TMZ analogues) demonstrated $\geq 7$ fold and $\geq 3$ fold more potent cytotoxicity respectively compared to TMZ in MGMT-expressing MB cell lines. Activity of the BAD mimetic ABT-737 was BCL2A1 and ABCB1 dependent, whereas the pan-BCL2 inhibitor obatoclax was effective as a single cytotoxic agent irrespective of $M C L 1, B C L 2$, BCL2A1, or $A B C B 1$ expression.

Conclusions: $A B C B 1$ is associated with high-risk MB; hence, inhibition of $A B C B 1$ by vardenafil may represent a valid approach in these patients. Imidazotetrazine analogues of $\mathrm{TMZ}$ and the $\mathrm{BH} 3$ mimetic obatoclax are promising clinical candidates in drug resistant MB tumours expressing MGMT and BCL2 anti-apoptotic members respectively.

Keywords: Medulloblastoma, ABCB1, MGMT, Etoposide, Temozolomide, Obatoclax

\section{Introduction}

Medulloblastoma $(\mathrm{MB})$ is the most frequent primary malignant brain tumour in children [1]. Currently the MB clinical staging system differentiates between standard-risk or high-risk disease depending on clinical findings and histologic subtype [2,3]. Standard risk describes children older than 3 years of age at diagnosis with totally or near totally resected, non-disseminated disease and classic or desmoplastic histology. High-risk patients have either disseminated disease, incomplete resection or are of the large cell or anaplastic histologic subtypes [4,5]. Treatment

\footnotetext{
* Correspondence: beth.coyle@nottingham.ac.uk

${ }^{1}$ Children's Brain Tumour Research Centre, Division of Child Health, Obstetrics and Gynaecology, School of Medicine, University of Nottingham, QMC, Nottingham NG7 2UH, UK

Full list of author information is available at the end of the article
}

generally consists of gross total surgical excision combined with radiotherapy and chemotherapy; however $30-40 \%$ of high risk and $15-20 \%$ of standard risk patients develop recurrence of disease resulting in poor survival outcome [1,3,6-12]. Long term survivors suffer from treatmentassociated endocrine, neurological, growth and neurocognitive complications that affect quality of life, in addition to having a substantial risk of secondary malignancy $[13,14]$. From a chemotherapy perspective, primary MBs are mainly treated with combination chemotherapies that include: etoposide, methotrexate, cisplatin, lomustine, cyclophosphamide and vincristine [11,15-17]. Recurrent and progressive tumours in children are treated with more intensive regimes frequently involving temozolomide (TMZ) and irinotecan although the prognosis for these patients is poor [1,18-22]. 
Chemotherapy is now widely accepted as part of standard therapy for MB. The high frequency of recurrence, however, supports the hypothesis that a substantial number of patients have intrinsically drug resistant tumours [23]. Chemotherapy treatment failure is particularly relevant in children under three years of age who are preferentially treated with chemotherapy alone to minimise the adverse effect of radiotherapy on the developing brain [16,24-26].

Classical multidrug resistance is often partly attributed to elevated expression of polyspecific ATP-dependent drug efflux pumps belonging to the ATP-binding cassette $(A B C)$ transporter super family. The three best characterised are ABCB1 (also known as P-glycoprotein or MDR1), ABCG2 (Breast Cancer Resistance Protein) and $\mathrm{ABCC} 1$ (multidrug resistance associated-protein 1 or MRP1) reviewed by Szakács et al. [27]. High expression of $\mathrm{ABCB} 1$ has previously been associated with chemoresistance and poor outcome in brain tumours including MB [28], glioma [29] and ependymoma (manuscript in preparation). We have also previously demonstrated that ABCB1 is expressed in a small subset of brain tumour cells and hypothesised that these cells are selected by current treatments resulting in relapse [30]. Since four of the drugs currently being used to treat primary and recurrent $\mathrm{MB}$ are $\mathrm{ABCB} 1$ substrates (etoposide, vincristine, methotrexate and irinotecan) [27] we would anticipate that overcoming/inhibiting ABCB1 could enhance the efficacy of current chemotherapy regimens.

Lomustine and TMZ are oral DNA alkylating cytotoxic drugs used for the treatment of primary and recurrent $M B$, respectively. The activity of both drugs depends on the absence of direct repair by O6-methylguanine-DNA-methyltransferase (MGMT) and proficient mismatch repair (MMR) [31]. Thus, over-expression of MGMT, a feature of more than half of $\mathrm{MB}$ patients in two recent studies $[32,33]$ can diminish the therapeutic efficacy of TMZ and lomustine. However, methylation of O6-guanine, the major cytotoxic lesion, comprises only 6\% TMZ-DNA adducts [34], TMZ also methylates N7-guanine and N3- adenine, generating lesions which are repaired by base excision repair (BER) facilitated by the enzyme poly ADP ribose polymerase (PARP). Inhibition of PARP has been shown to enhance TMZ activity in vitro and in vivo $[35,36]$. Recently, an alternative single agent approach has been shown to circumvent MGMT-mediated resistance in glioblastoma cell lines using novel imidazotetrazine TMZ analogues [37]. We wished to examine whether these agents were also able to effectively kill $\mathrm{MB}$ cells expressing high levels of MGMT.

Chemotherapy-induced cell cytotoxicity mainly occurs via the mitochondrial apoptotic pathway, regulated by the B-Cell lymphoma/leukaemia 2 (BCL2) family. Overexpression of anti-apoptotic BCL2 family proteins, such as BCL2, BCL-X $\mathrm{L}_{\mathrm{L}}$ MCL1 and BCL2A1, has been observed in many types of cancer including $\mathrm{MB}$ [38-41]. Hence, since the cloning of BCL2 25 years ago [42] many attempts have been made to target these pro-survival oncogenes therapeutically [43]. The most successful approach to target this pathway has been through the use of BCL2 homology 3 (BH3) mimetics; small molecules designed to mimic the $\mathrm{BH} 3$ domain found in pro-apoptotic members of the BCL-2 family. Recently two such small molecule inhibitors (ABT-737/ABT-263 and obatoclax) have entered clinical trial $[44,45]$. We have previously tested ABT-737 on $\mathrm{MB}$ cell lines in vitro and although it was able to potentiate the action of cisplatin and etoposide, it proved ineffective as a single agent [46]. ABT-737 is described as a $\mathrm{BAD}$ mimetic since it shows the same binding to BCL2, BCL- $\mathrm{X}_{\mathrm{L}}$ and $\mathrm{BCL}-\mathrm{w}$ as this $\mathrm{BH} 3$ pro-apoptotic protein. We needed to determine whether the lack of ABT-737 efficacy as a single agent was due to the expression of additional BCL2 family members, targetable by the paninhibitor obatoclax, or the fact that ABT-737 has recently been demonstrated to be an ABCB1 substrate in chronic lymphocytic leukaemia [47].

In this study we set out to investigate three potential reasons for chemotherapy failure in $\mathrm{MB}$ using a combination of patient tissue microarrays and early passage cell lines. We show that whilst all three mechanisms do indeed contribute to $\mathrm{MB}$ chemoresistance, each of them can be effectively circumvented using a combination of novel agents (vardenafil, N3-propargyl and obatoclax).

\section{Materials and methods}

\section{Patient characteristics}

Clinical and histological data for the Nottingham retrospective cohort are outlined in the Additional file 1: Table S1. Clinical details of patients included in tissue microarrays (TMA) obtained from German Cancer Research Centre DKFZ were previously published by Dubuc et al. [48].

\section{Cell culture}

Five new primary and recurrent $(\mathrm{R}) \mathrm{MB}$ cell lines were derived as previously described [30] at the Children's Brain Tumour Research Centre (CBTRC) (MED3, MED4, MED4R, MED5R and MED6) with approval from Local Research Ethics Committee. The tumours of origin were classified into molecular subtypes according to recent classification of MB subtypes [49-51]. Primary MB cell lines were cultured as monolayers and neurospheres as described previously [30]. The DAOY MB cell line was purchased from ATCC and cultured as recommended. UW228-3 was supplied by John R. Silber and grown as recommended [52]. A control Human Embryonic Kidney cell line (HEK-B1) stably expressing ABCB1 was provided as a gift by Rob Robey and cultured in DMEM with $10 \%$ serum and $500 \mu \mathrm{g} / \mathrm{ml}$ of G418. 


\section{Immunohistochemistry}

Immunohistochemistry (IHC) was performed using the Dako Envision Detection kit (DAKO REAL EnVision) [53]. Sections were counter-stained with haematoxylin (Leica Microsystems). As negative controls, adjacent or similar sections were processed with antibody diluent (Dako). The antibodies (Abs) used to stain the original patient samples with appropriate control for each $\mathrm{Ab}$ are summarised in Additional file 2: Table S2.

A total of 27 Nottingham MB patients diagnosed between January 1986 and January 2006 were analysed by IHC. Consent for tumour tissue use was taken in accordance with national tumour banking procedures (UK: 05/ MRE/04/70). A second TMA comprising 233 patient samples was obtained from the DKFZ [48]. Both TMAs were stained with the anti-ABCB1 Ab (C219, 1:40; Calbiochem) and patients with clear evidence of cell membrane staining were scored as positive by three independent reviewers who were blinded to clinical and patient molecular variables.

\section{Detection of $A B C B 1$ expression and inhibition of $A B C B 1$ function by flow cytometry}

To detect the percentage of $\mathrm{ABCB} 1$ expressing cells, 300,000-500,000 cells were incubated with 4E3 (anti$\mathrm{ABCB} 1 ; 1: 20$; Abcam) for 30 minutes at $37^{\circ} \mathrm{C}$ in fluorescent activated cell sorting (FACS) buffer (high glucose DMEM plus 5\% BSA). The cells were then washed twice with FACS buffer and incubated with Alexa Fluor ${ }^{\circ} 647$ goat anti-mouse IgG (1: 1000; Invitrogen) for 30 minutes on ice in the dark. As a control, cells were stained with secondary Ab alone (Alexa Fluor 647; Invitrogen). Any unbound $\mathrm{Ab}$ was removed by washing the labelled cells twice with FACS buffer. To investigate ABCB1 function, cells were incubated with Rhodamine 123 (Rh123, Sigma; $\mathrm{ABCB} 1$ flourescent substrate), with and without $\mathrm{ABCB} 1$ inhibitors verapamil (VPL, Sigma), and vardenafil (TRCCanada) at concentrations given in figure legends. Fluorescence was detected on a Cytomics FC500 flow cytometer (Beckman Coulter) and analysed using WinMDI version 2.8. Data presented are mean \pm SEM of three independent experiments.

\section{Quantitative polymerase chain reaction}

RNA extraction from cultured cells was performed using mirVana miRNA Isolation kit (Ambion) and transcribed into cDNA using reverse transcriptase (Superscript III; Invitrogen). The resulting cDNA template was amplified and sequenced using primers previously published by Kumar et al. [54]. PCR products were sequenced on the forward and reverse strands at the DNA sequencing lab at the University of Nottingham.

Quantitative reverse transcription PCR (QRT-PCR) analysis was carried out using the CFX96 real time PCR machine (BIO-RAD) and iQ SYBR Green SuperMix (BIO-RAD) to assess the expression. Primers for $\mathrm{MB}$ molecular subtyping (WIF1, SFRP1, NPR3 and KCNA1) were designed and published by Zhao et al. [55]. ABCB1 primers were as published by Valera et al. [56]. The house-keeping gene GAPDH (Forward primer 5' ATGT TCGTCATGGGTGTGAA 3'; reverse primer 5'GTCT TCTGGGTGGCAGTGAT 3') was used as a control to normalise the data, as the cycle threshold value for GAPDH expression was consistent across the sample set. Relative values of transcripts were calculated using the Pfaffl equation [57]. Results are presented as mean \pm SEM of three independent experiments, each experiment was performed in triplicate.

To identify MYCC and MYCN copy number elevation in MB samples, genomic DNA extraction from frozen cell pellets was performed as previously described [30]. Quantitative PCR (QPCR) analysis was carried out using the CFX96 real time PCR machine (BIO-RAD) and $\mathrm{iQ}$ SYBR Green SuperMix (BIO-RAD). DNA isolated from D458 cells was used as a positive control for MYCC and a previously described sample of anaplastic astrocytoma with $M Y C N$ amplification was used as a positive control for MYCN [58]. MYCC and MYCN copy numbers were measured relative to the endogenous control RPLPO and results for each sample were normalised to the copy number of diploid human DNA in Pfaffl equation [57]. Primer sequences have been previously published by Ryan et al. [59].

\section{Western blotting}

SDS PAGE and Western blotting were performed as previously described [46]. Blots were probed with the following Abs: mouse anti-ABCB1 (anti-C219 mouse monoclonal Ab; Calbiochem1:100), anti-MGMT (Millipore 1:100), rabbit anti-BCL2 (Cell Signaling clone 50E3 1:1000), rabbit anti BCL2A1 (Cell Signaling 1:1000), Rabbit anti-MCL1 (Santa Cruz 1:500) and either mouse anti-GAPDH (Sigma) or rabbit anti- $\beta$-tubulin (Cell Signalling Technology) 1:1000 as loading controls. All primary Abs were detected using goat anti-mouse/rabbit IgG HRPlinked secondary Ab (Cell Signalling Technology 1:2000) and enhanced chemoluminescence (GE Health Care Life Science) performed according to the manufacturer's protocol.

\section{Clonogenic assay}

Cell growth inhibition was estimated after treatment of single cells in 6 well plates. Cells (150-200) were seeded into 6 well plates, and allowed to adhere (4-8 hours) before drug treatment. At the outset the clonogenic range was established for each drug and used to derive $\mathrm{IC}_{50}$ drug concentrations. The range of drug concentrations tested and the length of the treatment period was 
dependent on the drug being tested. Cells were incubated with: 0-8 $\mu \mathrm{M}$ etoposide (Sigma) for 2 hours; 0-50 $\mu \mathrm{M}$ ABT-737 (Benzamide; Selleckchem) for 24 hours; 0-3 $\mu \mathrm{M}$ obatoclax mesylate (GX15-070; Geminx) for 24 hours; 0-800 $\mu \mathrm{M}$ (MGMT+) or 0-100 $\mu \mathrm{M}$ (MGMT-) TMZ for 2 hours; and up to $200 \mu \mathrm{M} N-3$ sulfoxide and N-3 propargyl for 2 hours. Inhibitors were added for the same length of time as the drug, either in the same well or separately to assess toxicity. For experiments to investigate the role of ABCB1 in mediating drug resistance; verapamil (10, $20 \mu \mathrm{M}$ Sigma) and vardenafil (5, $10 \mu \mathrm{M}$ Toronto Research Chemicals) were tested. To investigate potentiation of TMZ or N3-propargyl by circumvention of BER the PARP inhibitor rucaparib (0.4 $\mu$ M AG 014699; Selleckchem) was tested. Following drug $+/-$ inhibitor addition, the cultures were then maintained at $37^{\circ} \mathrm{C}$ in a humidified atmosphere containing 5\% v/v $\mathrm{CO}_{2}$, and allowed to grow for 6 (MED1), 7 (DAOY and UW228-3), or 12 (MED3) days depending on the cell line's doubling time. Colonies were fixed with $4 \% \mathrm{w} / \mathrm{v}$ paraformaldehyde and stained with $0.1 \% \mathrm{w} / \mathrm{v}$ crystal violet (Sigma). Colonies that contained more than 50 cells ( $\geq 6$ doublings) were counted. The colonies were double-scored (one of the scorers being blind to the culture conditions). Clonogenic assays were repeated at least three times as independent experiments, each with internal duplicate cultures. The percentage of clonogenic survival was expressed relative to vehicle controls.

\section{Statistical analysis}

Log-rank analysis on Kaplan-Meier curves determined the significance of overall survival (OS) and progression free survival (PFS) using SPSS version 21 statistical software (IBM). Differences between pairs of groups were determined by the Student's $t$-test or Chi-squared test using GraphPad prism version 5.00 (San Diego California, USA) or IBM SPSS version 21 respectively. Response to TMZ and TMZ analogues between groups was assessed using one way ANOVA. $P$ values $<0.05$ were considered significant.

\section{Results}

\section{$A B C B 1$ expression is associated with high risk MB}

There is evidence supporting a role for MGMT and the BCL2 family in MB chemotherapeutic response; however, the evidence supporting ABCB1 was more equivocal $[28,33,41]$. We therefore set out to identify whether there were clinical correlates of ABCB1 expression in a retrospective Nottingham $\mathrm{MB}$ patient TMA. In total 12 of 27 samples (44\%) were positive for ABCB1 expression, and the majority of these were high risk patients, but this relationship was not statistically significant $(P \geq$ $0.05)$, presumably due to the small number of patient samples. We then analysed ABCB1 expression across a larger German DKFZ TMA. On this array 42\% (99/233) of samples were positive for ABCB1 expression and ABCB1 was significantly more likely $(P=0.035)$ to be expressed in samples from high risk patients (Figure 1A). There was no significant difference between age, gender, resection status, and recurrence group of the two studies $(P>0.05$, Additional file 3: Table S3). In each case positive samples contained a subpopulation of cells with membranous $\mathrm{ABCB} 1$ expression (0.1-11\%). This high frequency of $\mathrm{ABCB} 1$ expression in $\mathrm{MB}$ patients and association with high risk clearly justified its inclusion in our chemoresistance analyses of patient derived cell lines.

\section{Characterisation of MB cell lines and their tumour of origin}

To investigate the mechanisms of drug resistance in $M B$, we have adopted an approach that involves establishing cell lines from patients' primary and recurrent tumours [30]. In the current work, we describe 6 newly derived MB cell lines (including the previously described MED1) [30]. The clinical characteristics of these patients are presented in supplementary Additional file 4: Table S4. The tumours from which the cell lines were derived have been assigned to $\mathrm{MB}$ molecular subtypes [60,61] using $\mathrm{IHC}$ for $\beta$ catenin, Gli1, NPR3 and KCNA1 (Additional file 5: Figure $\mathrm{S} 1$ ), and sequencing of the $\beta$-catenin gene (CTNNB1). The corresponding cell lines were sub-grouped by comparing expression of representative genes [WIF1 (WNT), SFRP (SHH), NPR3 (Group 3), and KCNA1 (Group 4)] to foetal cerebellum (Additional file 6: Figure S2, [55]). MYCC and $M Y C N$ copy number were determined (Additional file 7: Figure S3) and $\beta$-catenin sub-grouping was again confirmed by sequencing CTNNB1 (Additional file 8: Figure S4). These data are summarised in Table 1. Our data therefore suggest that MED1 is derived from a large cell anaplastic Group 4 tumour with MYCN amplification. MED3 is derived from a classical Group 3 tumour, MED4, and MED4R result from Group 3 tumours with $\mathrm{MYCN}$ gain. In each case the cell lines maintain the characteristics of their tumour of origin. MED5R and MED6 are derived from WNT subtypes ( $\beta$-catenin positive) large cell anaplastic and classical tumours respectively. MED5R and MED6 have heterozygous mutations (TCT-TTT) at codons 33 and 37 (of CTNNB1) respectively. The MED5R cell line maintained the mutation in culture whereas the MED6 cell line reverted to wild type (Additional file 8: Figure S4). We also established that UW228-3 cells are NPR3 positive with MYCC gain. DAOY cells, on the other hand proved difficult to classify, although, have been classified recently as $\mathrm{SHH}$ by Pambid et al. [62].

\section{$A B C B 1$ expression and function is maintained in $M B$ cell lines}

ABCB1 expression was assessed in each of the tumours of origin by IHC (Additional file 9: Figure S5). The percentage of $\mathrm{ABCB} 1$ expressing cells ranged from $\sim 1 \%$ in 


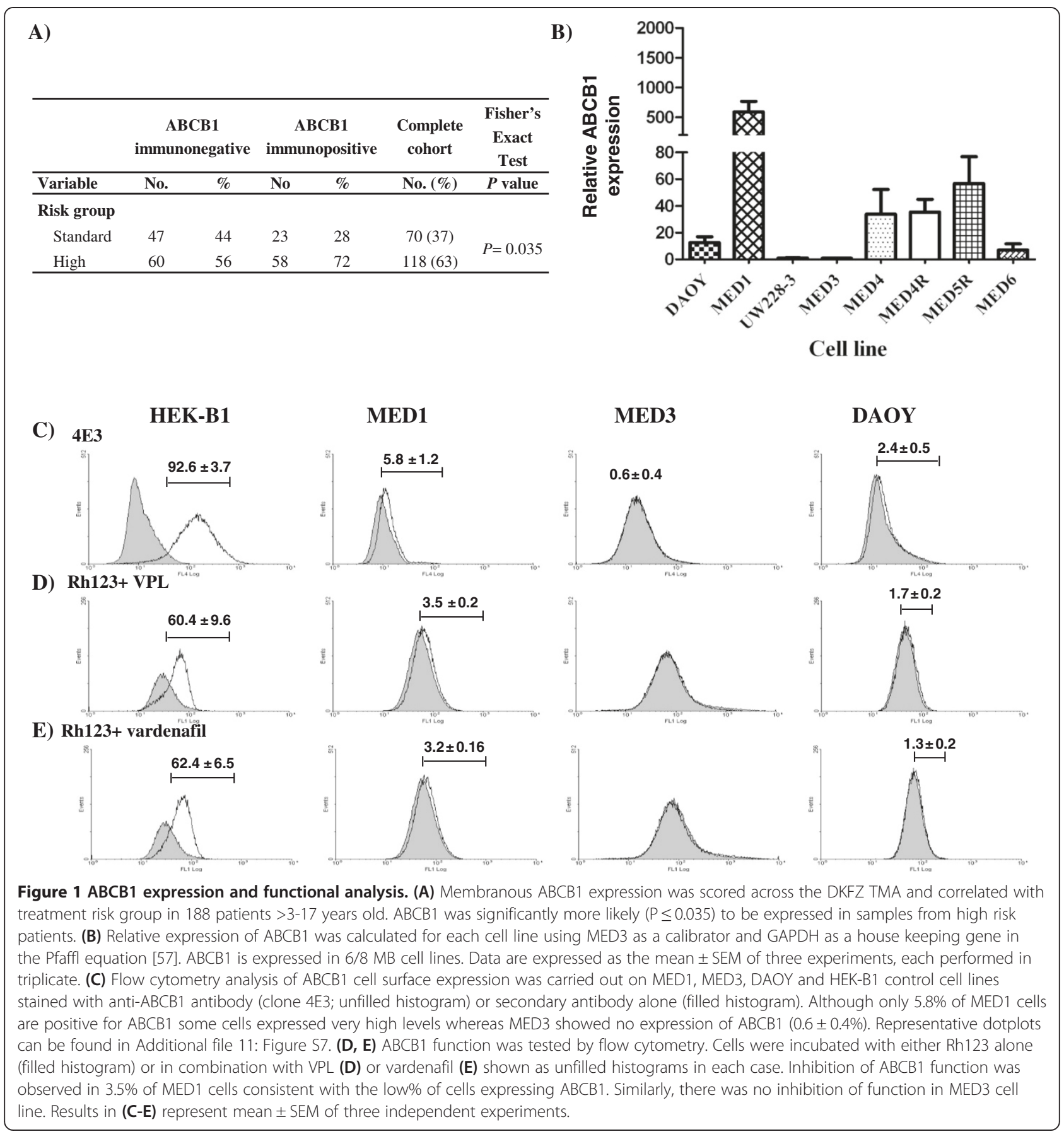

the MED6 to $11.2 \%$ in the MED1 tumour of origin (Table 1). ABCB1 expression was then assessed in the 6 CBTRC cell lines derived from these MBs as well as two more generally studied MB cell lines, DAOY and UW228-3, by QRT-PCR (Figure 1B). In common with the tumour of origin, MED1 cells expressed the highest levels of $\mathrm{ABCB} 1 \mathrm{mRNA}$ (Figure 1B) and glycosylated $A B C B 1$ protein (Additional file 10: Figure S6), thus confirming maintenance of $\mathrm{ABCB} 1$ expression in culture. MED4, MED4R and MED5R demonstrated intermediate
ABCB1 expression whereas MED3 cells expressed negligible mRNA and protein, again correlating with protein expression levels in primary tumours (Figure 1B, Additional file 10: Figure S6, Table 1). DAOY cells showed intermediate ABCB1 expression, whereas UW228-3 cells expressed low ABCB1 mRNA and protein levels. Three cell lines demonstrating high (MED1), intermediate (DAOY) and low (MED3) ABCB1 expression were further investigated for cell surface expression and function of $A B C B 1$ by flow cytometry and compared to HEK-B1 cells stably expressing 
Table 1 Characterisation of MB original patient samples and their derived cell lines

\begin{tabular}{|c|c|c|c|c|c|c|c|c|c|c|}
\hline \multirow[t]{2}{*}{ Name } & \multicolumn{5}{|c|}{ Tumour } & \multirow[b]{2}{*}{$\begin{array}{c}\text { MB } \\
\text { subtype }\end{array}$} & \multicolumn{4}{|c|}{ Cell lines } \\
\hline & Histology & $\begin{array}{l}\text { IHC MB subtype } \\
\text { marker }\end{array}$ & $\begin{array}{l}\text { CTNNB1 } \\
\text { mutated }\end{array}$ & $\begin{array}{c}\text { IHC } \\
\text { ABCB1 \% }\end{array}$ & $\begin{array}{c}\text { IHC } \\
\text { MGMT }\end{array}$ & & $\begin{array}{l}\text { Subtype } \\
\text { QRTPCR }\end{array}$ & MYC status & $\begin{array}{l}\text { CTNNB1 } \\
\text { mutated }\end{array}$ & $\begin{array}{c}\text { MB } \\
\text { subtype }\end{array}$ \\
\hline MED 1 & LC/A & KCNA1 & No & 11.2 & - & Group 4 & KCNA1 positive & MYCN Amplified & No & Group 4 \\
\hline MED 3 & Classical & Moderate NPR3 & No & 0 & + & Group 3 & NPR3 positive & Normal & No & Group 3 \\
\hline MED4 & LC/A & NPR3 & No & 1.9 & + & Group 3 & NPR3 positive & MYCN gain & No & Group 3 \\
\hline MED4R & $L C / A$ & NPR3 & No & 4.5 & + & Group 3 & NPR3 positive & MYCN gain & No & Group 3 \\
\hline MED5R & LC/A & $\beta$-catenin & Yes & 6.2 & + & WNT* & NPR3 positive & Normal & Yes & WNT \\
\hline MED6 & Classical & $\beta$-catenin & Yes & 1.2 & + & $\mathrm{WNT}^{*}$ & NPR3 positive & Normal & No & Group 3 \\
\hline UW228-3 & Classical & NA & NA & NA & NA & Group 3 & NPR3 positive & MYCC gain & No & Group 3 \\
\hline DAOY & Desmoplastic & NA & NA & NA & NA & $\mathrm{SHH}$ ? & None & Normal & No & SHH $[62]^{* *}$ \\
\hline
\end{tabular}

Abbreviation: $\mathrm{LC} / \mathrm{A}=$ large cell/anaplastic medulloblastoma, $\mathrm{R}=$ recurrent, $\mathrm{IHC}=$ immunohistochemistry, WNT = $\beta$-catenin positive, Group $3=\mathrm{NPR} 3$ positive, Group 4= KCNA1 positive, MED4 and MED4R are from the same patient.

*Frozen tissue from MED5R and MED6 has CTNNB1 mutation at codon 33 and 37 respectively. NA= tumour material not available. ${ }^{* *}$ DAOY cell line was characterised as SHH by Pambid et al. [62].

ABCB1 (Figure 1C-E). For MED1 $5.8 \pm 1.2 \%$ cells were positive for $\mathrm{ABCB} 1$ with some cells showing very high expression (Figure 1C, Additional file 11: Figure S7). MED3 cells demonstrated negligible ABCB1 expression (0.6 \pm $0.4 \%)$. Within the DAOY cell population $2.4 \pm 0.5 \%$ cells expressed consistently low ABCB1 levels (See Figure 1C, Additional file 11: Figure S7). ABCB1 function was investigated with the Rh123 extrusion assay. Extrusion of Rh123 in MED1 was inhibited by $20 \mu \mathrm{M}$ VPL (right shifted cell histogram) and $10 \mu \mathrm{M}$ vardenafil (Figure 1D,E) in $~ 3.5 \%$ of cells. Thus both agents are able to inhibit Rh123 extrusion in $60 \%$ of ABCB1 expressing (3.5/5.8) cells. Similar levels of inhibition (54-66\%) were observed with both inhibitors in HEK-B1 and DAOY cells. MED3 cells failed to extrude Rh123 consistent with lack of ABCB1 cell surface expression.

\section{Co-treatment with $A B C B 1$ inhibitors VPL and vardenafil results in increased etoposide cytotoxicity}

To further investigate $\mathrm{ABCB} 1$ function in vitro, clonogenic survival was assessed in ABCB1 negative MED3 and 2 $\mathrm{ABCB} 1$ positive (MED1 and $\mathrm{DAOY}$ ) $\mathrm{MB}$ cell lines in response to etoposide alone or in combination with the $\mathrm{ABCB} 1$ inhibitors VPL and vardenafil. The $\mathrm{IC}_{50}$ concentrations for etoposide reflected the expression levels of $\mathrm{ABCB} 1$, with MED1 demonstrating the greatest degree of resistance to etoposide (MED1 $1.92 \mu \mathrm{M}$, DAOY $1 \mu \mathrm{M}$, and MED3 $0.5 \mu \mathrm{M}$ ) (Figure 2). Both ABCB1-expressing cell lines demonstrated significantly increased etoposide sensitivity when cells were treated with etoposide at the $\mathrm{IC}_{50}$ concentration plus inhibitors VPL or vardenafil compared to cells treated with etoposide alone (MED1 $P<$ 0.0001 in all cases, Figure 2A; DAOY $P<0.001$ in all cases except $5 \mu \mathrm{M}$ vardenafil $P=0.02$; Figure $2 \mathrm{~B}$ ). Conversely, no significant potentiation of cell cytotoxicity was observed when MED3 cells were treated with etoposide plus ABCB1 inhibitors $(P>0.05$; Figure $2 C)$. These results confirm that etoposide cytotoxicity in MB cell lines is significantly influenced by ABCB1 expression. Moreover, our in vitro assays confirm that vardenafil significantly inhibits ABCB1.

\section{Obatoclax-induced apoptosis in MB cell lines is} independent of MCL1, BCL2A1 and $A B C B 1$ expression

We have previously shown that $M B$ cell lines express MCL1 and BCL2 anti-apoptotic proteins, and that the BH3 mimetic ABT-737, although able to potentiate activity of chemotherapeutic drugs, failed to induce apoptosis as a single agent in MB cell lines [46]. The lack of efficacy of ABT-737 could not be explained by BCL2 and MCL1 expression alone. Therefore we sought to further investigate the efficacy of ABT-737 against MB cell lines and compare it to the new anti-BCL2 drug obatoclax. We first looked at anti-apoptotic (BCL2, MCL1 and BCL2A1) protein expression in three representative $M B$ cell lines, including UW228-3 since this was used in our previous study (Figure 3A). Whereas BCL2 and MCL1 were differentially expressed, consistent with our previous report [46], all 3 cell lines expressed BCL2A1. Previous studies on leukaemia cell lines have shown that ABT-737 is a substrate for $\mathrm{ABCB} 1$ [47], therefore the pro-apoptotic activity of ABT-737 and obatoclax were tested on these 3 cell lines with and without the ABCB1 inhibitor VPL (Figure 3B, C). ABT-737 was tested up to maximum $50 \mu \mathrm{M}$ concentration $(\mathrm{DMSO}>0.1 \%$ ) but it was only able to reduce cell colony formation by approximately $20 \%, 15 \%$ and $20 \%$ in DAOY, MED1 and UW228-3 respectively. There was a small but significant increase in ABT-737 efficacy when $\mathrm{ABCB} 1$ positive $\mathrm{MB}$ cells were treated with ABT-737 $(50 \mu \mathrm{M})$ plus $10 \mu \mathrm{M}$ of VPL $(P<0.03$ for MED1 and $P<$ 0.02 for DAOY; Figure 3B) but no effect of VPL was found on ABCB1 negative UW228-3 cells $(P \geq 0.05)$. Obatoclax caused significantly decreased clonogenic cell survival resulting in less than $2 \%$ clonogenic survival at the 


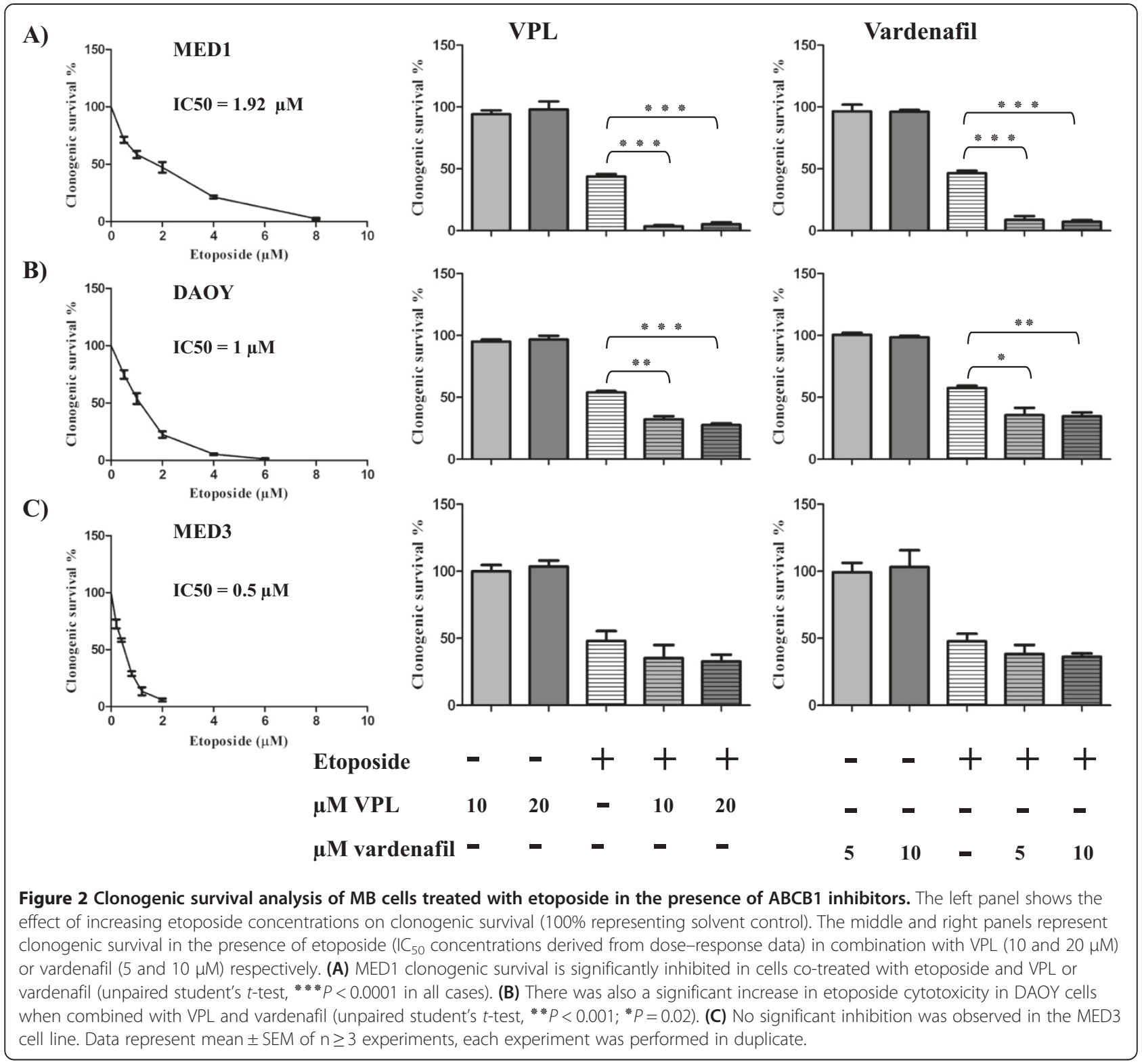

highest concentration $(3 \mu \mathrm{M})$ in all 3 cell lines (Figure $3 \mathrm{C}$ ). The $\mathrm{IC}_{50}$ of obatoclax in DAOY, MED1 and UW228-3 was $0.27,0.3$ and $0.42 \mu \mathrm{M}$ respectively. Most importantly, there was no significant change in colony formation following treatment of cells with obatoclax and VPL $(P>$ 0.05 ; Figure $3 \mathrm{C}$ ). Our in vitro results suggest that obatoclax is not an ABCB1 substrate; can inhibit BCL2, MCL1 and BCL2A1, and therefore, is more effective than ABT737 since it can function as a single agent.

\section{Growth inhibition by the two novel TMZ analogues} ( $\mathrm{N}-3$ sulfoxide and $\mathrm{N}-3$ propargyl) is MGMT independent TMZ cytotoxicity depends on the absence of MGMT enzyme and functioning MMR [31]. MGMT expression was assessed in all tumours of origin for our cell lines by IHC
(Additional file 12: Figure S8, Table 1). Only MED1 was MGMT negative, with all other samples showing strong MGMT expression. DAOY, UW228-3 and MED3 MB cell lines all show high MGMT expression while MED1 cells show no MGMT expression by Western blotting, consistent with the observed expression in primary tissue samples from the corresponding tumours (Figure 4A, Additional file 12: Figure S8). The efficacy of TMZ and two novel imidazotetrazine TMZ analogues $(\mathrm{N}-3$ sulfoxide and $\mathrm{N}-3$ propargyl; Figure 4B) were compared using the clonogenic assay. Clonogenic survival was concentration-dependent in all 4 cell lines. DAOY, UW228-3 and MED3 were resistant to $\mathrm{TMZ}\left(\mathrm{IC}_{50}=290-540 \mu \mathrm{M}\right.$; Figure $\left.4 \mathrm{C}\right)$; in contrast MED1 cells were sensitive $\left(\mathrm{IC}_{50}=31 \mu \mathrm{M}\right.$; Figure $\left.4 \mathrm{C}\right)$. All $\mathrm{MB}$ cell lines were sensitive to sulfoxide and propargyl 
A)

B)

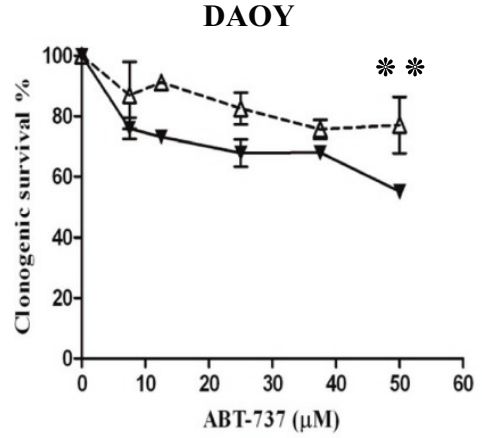

C)

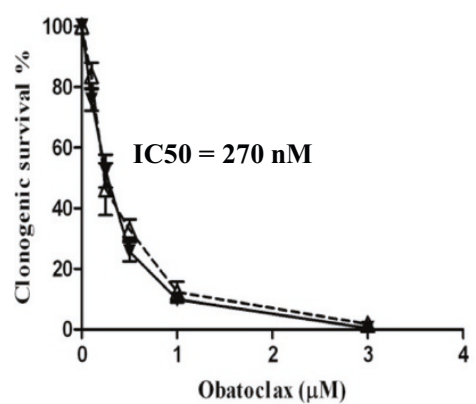

BCL2 26 kDa

MCL1 36 kDa

$\beta$-Tubulin $\sim 50 \mathrm{kDa}$

BCL2A1 18 kDa

$\beta$-Tubulin $\sim 50 \mathrm{kDa}$

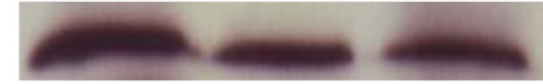

MED1
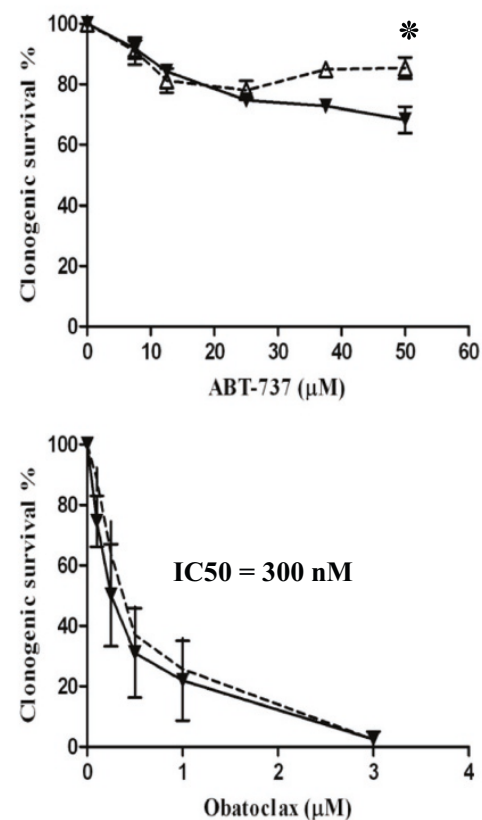

$-A--$ drug

$\rightarrow$ drug + VPL

UW228-3
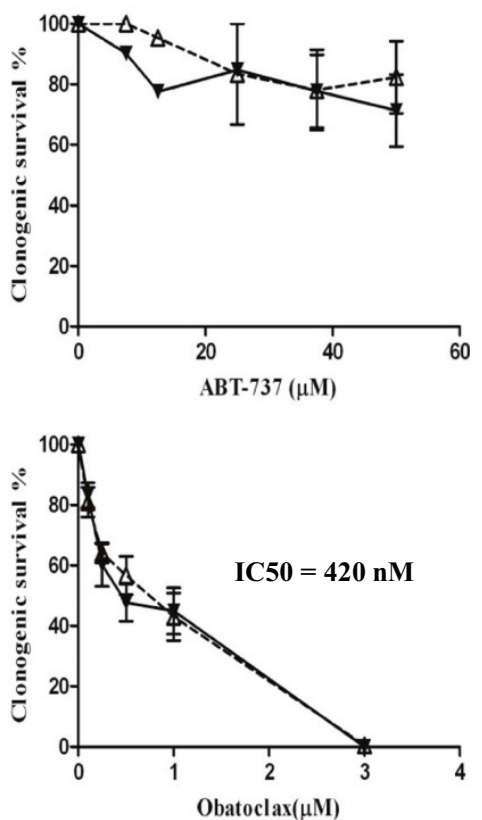

Figure 3 BCL2 family protein expression and functional analysis. BCL2A1 and ABCB1 limit response to ABT-737 but not obatoclax. (A) DAOY, UW228-3 and MED1 cells were analysed by Western blotting for expression of anti-apoptotic BCL2 protein family member, BCL2 is expressed in DAOY and MED-1 whereas no expression was observed in UW228-3 cells. MCL1 is expressed in DAOY and UW228-3 whereas MED-1 displayed no expression. BCL2A1 was expressed at a low level in all three cell lines. $\beta$-tubulin served as a loading control. (B, C) Clonogenic survival of MB cells in the presence of ABT-737 (B) or obatoclax (C) alone (dotted line) or in combination with $10 \mu \mathrm{M} \mathrm{VPL}$ (solid lines). Although $\mathrm{C}_{50}$ values were not reached, significant potentiation of ABT 737 function was observed at $50 \mu \mathrm{M}$ concentration in combination with VPL in DAOY and MED1 cell lines (unpaired student's t-test, ${ }^{* *} P=0.03 ;{ }^{*} P=0.02$ respectively). Conversely, obatoclax $I C_{50}$ values were in the nanomolar range for all 3 cell lines and there was no potentiation when combined with VPL. Results from B and C represent mean \pm SEM of $n \geq 3$ experiments, all performed in duplicate.

analogues independent of MGMT expression (sulfoxide $\mathrm{IC}_{50} 15-40 \mu \mathrm{M}$ whereas propargyl $\mathrm{IC}_{50} 42.4-96.3 \mu \mathrm{M}$; Figure 4C). To investigate whether BER was also able to modulate response we determined the $\mathrm{IC}_{50}$ concentrations for TMZ and the propargyl analogue when cells were treated in combination with the PARP inhibitor rucaparib (Additional file 13: Figure S9). There was considerable chemosensitisation of TMZ by rucaparib in
MGMT expressing DAOY, MED3 and UW228-3 cell lines (1.9 fold $P=0.02,2.7$ fold $P=0.002$ and 2.2 fold $P=0.029$ respectively; Table 2, Additional file 13: Figure S9). There was however no potentiation of propargyl cytotoxicity in combination with rucaparib (Table 2, Additional file 13: Figure S9). These results suggest that in MB cells cytotoxicity induced by the N-3 propargyl analogue is independent of MGMT and BER. 
A)

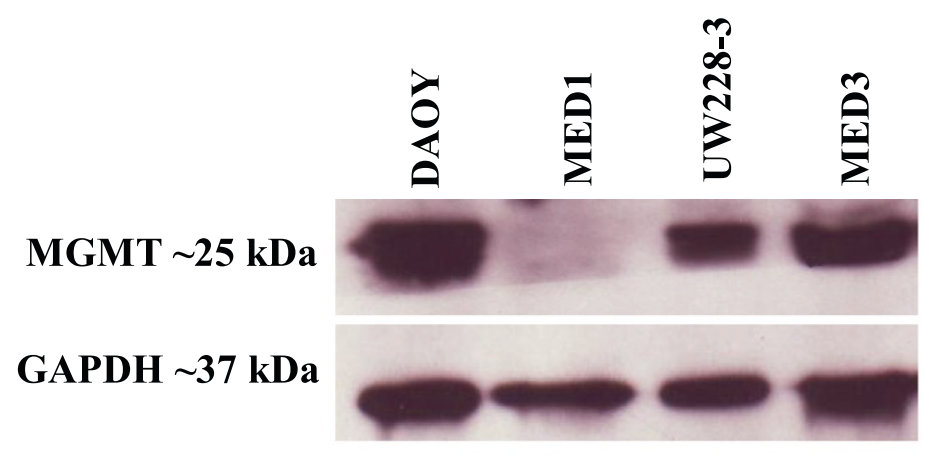

B)<smiles>[R]n1nnc2c(C(N)=O)ncn2c1=O</smiles>

$\underline{R}$

$\mathrm{CH}_{3}$

TMZ

$\mathrm{CH}_{2} \mathrm{C} \equiv \mathrm{CH}$ Propargyl

$\mathrm{CH}_{2} \mathrm{SOCH}_{3} \quad$ Sulfoxide

C)

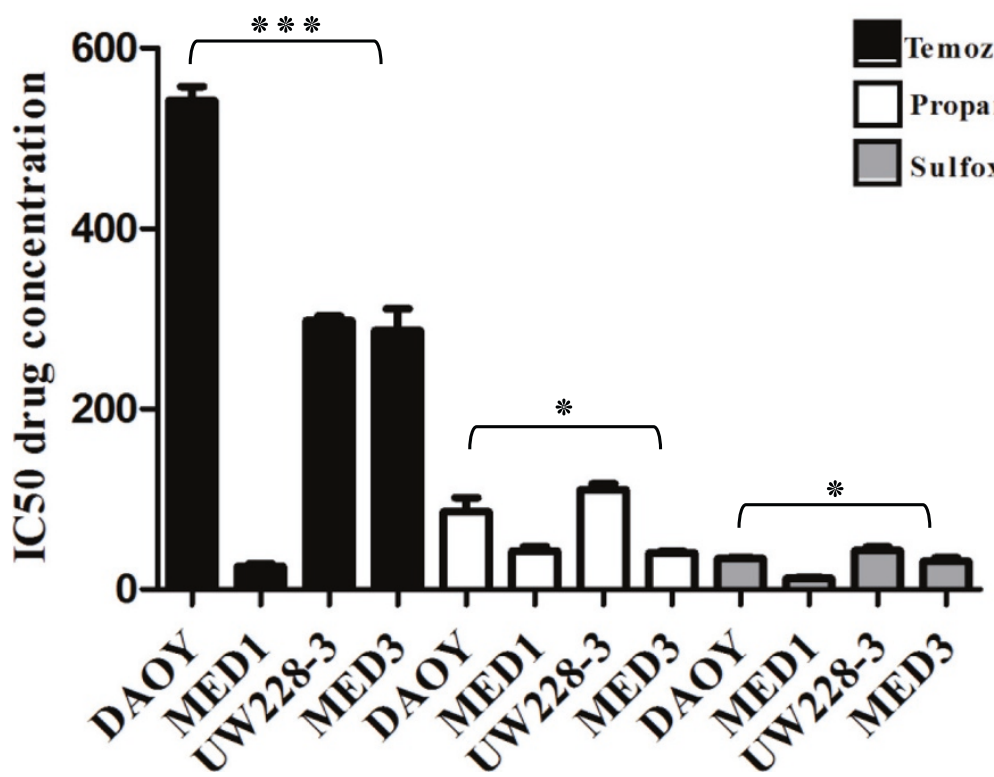

Figure 4 MGMT expression and response to TMZ, propargyl and sulfoxide imidazotetrazine analogues. (A) Relative levels of MGMT expression were determined by Western blotting. DAOY, UW228-3 and MED3 cells showed high expression of MGMT while no expression was observed in MED1 cells. (B) Chemical structure of TMZ, propargyl and sulfoxide, shows different N3 groups. (C) Clonogenic survival was determined as in Figures 2, and 3, the data represent the $I_{50}$ values (mean $\pm S E M, n \geq 3$ ) TMZ inhibited survival in an MGMT-status dependent manner (IC 50 at 290-540 $\mu \mathrm{M}$ in MGMT positive cells (DAOY, UW228-3 and MED3) compared to $31 \mu \mathrm{M}$ in MGMT negative MED1 cells). Propargyl and sulfoxide derivatives of TMZ inhibited survival at 40-80 and 20-40 $\mu \mathrm{M}$ respectively in all cell lines, showing no dependence on MGMT expression (unpaired student's t-test, ${ }^{*}{ }^{*}{ }^{*} P<0.0001 ;{ }^{*} P<0.05$ ).

\section{Discussion}

Benefit of adjuvant chemotherapy has been demonstrated in children [10] particularly those under 3 years of age with desmoplastic MB [3,9,10,15,16,25]. However, particularly in high risk disease and in children under 3 years of age with classic and anaplastic $\mathrm{MB}$, chemotherapy failure due to drug resistance is a recognised limitation to cure. There are many aspects to chemotherapy resistance with protective mechanisms operating at each stage of the cytotoxic process. We have sought here to investigate three basic mechanisms that are key to effective chemotherapy cytotoxicity and resistance. Firstly, chemotherapeutic drugs 
Table 2 Toxicity and efficacy of TMZ and propargyl in combination with PARP inhibitor rucaparib in MB cell lines

\begin{tabular}{|c|c|c|c|c|c|c|}
\hline Cell line & $\mathrm{IC}_{50} \mathrm{TMZ}$ & $\mathrm{IC}_{50} \mathrm{TMZ}+$ Rucaparib & PF & $I_{50}$ Propargyl & $I_{50}$ Propargyl + Rucaparib & $\mathrm{PF}$ \\
\hline DAOY & $540 \pm 70.2$ & $253 \pm 35.1$ & $1.9^{*}$ & $68.3 \pm 26.2$ & $47.9 \pm 4.6$ & 1.4 \\
\hline MED1 & $31 \pm 12.4$ & $26.8 \pm 10.9$ & 1.2 & $42.2 \pm 9.5$ & $43.4 \pm 14$ & 1.0 \\
\hline UW228-3 & $290 \pm 14.8$ & $129.5 \pm 12$ & $2.2^{*}$ & $96.3 \pm 21.2$ & $94.3 \pm 38$ & 1.0 \\
\hline MED3 & $332.9 \pm 81.8$ & $124.7 \pm 55.3$ & $2.7^{* *}$ & $53.6 \pm 16.8$ & $56.3 \pm 26.6$ & 1.0 \\
\hline
\end{tabular}

Abbreviation: $\mathrm{IC}_{50}=$ concentration resulting in $50 \%$ inhibition. $\mathrm{PF}=$ potentiation factor. ${ }^{*}{ }^{*} \mathrm{P}=0.002 ;{ }^{*} P<0.05$ (unpaired student's $t$-test). Result of $\mathrm{n} \geq 3$ experiments, all performed in duplicate.

must remain in the tumour cell long enough to damage DNA. Secondly, this damage must not be repaired. Thirdly, downstream apoptosis mechanisms must be active. By studying a set of MB cell lines we have demonstrated that all of these processes reducing cytotoxicity are active, but can be effectively inhibited or circumvented. Firstly, we have demonstrated that $>40 \%$ of MB tumours express the ABCB1 multi-drug transporter, which is able to export many of the currently used chemotherapeutic drugs. There was no difference in ABCB1 expression between the 4 molecular subtypes (data not shown). Importantly, our in vitro data shows that export by ABCB1 could be inhibited resulting in increased cytotoxicity. Secondly, we have shown that although MGMT is expressed in the majority of MB patients' tumours, and is able to directly repair the effects of DNA alkylating agents it cannot repair the effects of two novel imidazotetrazine derivatives of TMZ (N-3 sulfoxide and N-3 propargyl) in MB cells. Thirdly, our data indicate that, despite the expression of several BCL2 antiapoptotic family members, the BH3 mimetic obatoclax is effective as a single agent in MB.

Multidrug transporters serve as a major mechanism of defence in cancer chemotherapy. We hypothesise that the treatment of MB with current chemotherapeutic drugs, although effective as adjuvant therapy, leads to selection of an $\mathrm{ABCB} 1$ transporter expressing sub-populations of cells that in time can give rise to a more resistant tumour [63]. Importantly we have shown that in the DKFZ array $\mathrm{ABCB} 1$ expression is associated with patients that fall into the high risk category, which despite more aggressive therapy have a poorer outcome $[2,6,7]$. The concentration of etoposide used to achieve an $\mathrm{IC}_{50}$ in the $\mathrm{ABCB} 1$ positive MED1 cell line was slightly above the concentration used in clinic [64] while the MED3 $\mathrm{IC}_{50}$ was below the dose limiting toxicity. The data suggest however that the application of drugs that circumvent $\mathrm{ABC}$ transporters could therefore represent a valid addition to current $\mathrm{MB}$ chemotherapy regimens, particularly in high risk MB. We have used two inhibitors to overcome $\mathrm{ABCB} 1$ resistance in $\mathrm{MB}$ cells. VPL (a calcium channel blocker) is a nonspecific $A B C B 1$ inhibitor and its low affinity to $A B C B 1$ necessitated use of a high dose to block ABCB1 in clinical trials, resulting in unacceptable cardiac toxicity [65]. Vardenafil is a phosphodiesterase type 5 inhibitor used to treat children and infants with pulmonary arterial hypertension and portal hypertension with minimal adverse effects at concentrations above those indicated in our study [66,67]. It has been previously shown that vardenafil can specifically block $A B C B 1$ transporter function and enhance blood-brain and blood-brain tumour barrier permeability thereby enhancing delivery of herceptin to the brain in mice bearing intracranial breast and lung cancer [68,69]. Our results showed that vardenafil enhances etoposide cytotoxicity in ABCB1-expressing MB cell lines. The activity of vardenafil in each of our assays was equivalent to that of the non-specific $A B C B 1$ inhibitor verapamil. Thus, vardenafil is a good potential candidate for combination with current chemotherapeutics in patients with $\mathrm{MB}$ and should now be tested in vivo in pre-clinical models.

Many efforts have been made towards development of small molecules able to overcome the anti-apoptotic activity of anti-apoptotic BCL2 family proteins. ABT-737 can overcome BCL2 and BCL- $\mathrm{X}_{\mathrm{L}}$ and is currently in phase 1 clinical trial in small cell lung cancer (SCLC) and chronic lymphocytic leukaemia [45,70]. Although effective as a single agent in SCLC and leukaemia, ABT737 was not able to induce apoptosis as a single agent in $\mathrm{MB}$ cells $[46,71,72]$. It has been previously shown that ABT-737 function can be limited by BCL2A1 and MCL1 protein expression [73-75]. Additionally, ABT737 has been demonstrated to be a substrate for ABCB1 and $A B C C 1[47,76]$. Our data suggest that ABT-737 induction of apoptosis in $\mathrm{MB}$ is dependent of both BCL2A1 and ABCB1 protein expression. Using an $A B C B 1$ inhibitor did significantly potentiate the activity of ABT-737 in MB cells; however the $\mathrm{IC}_{50}$ concentration was still not reached and these concentrations would result in significant toxicity in vivo $[77,78]$. Obatoclax, on the other hand readily induced apoptosis, regardless of $\mathrm{BCL} 2 \mathrm{~A} 1$ and $\mathrm{ABCB} 1$ protein expression, at concentrations below the dose limiting toxicity concentration observed in phase 1 clinical trial [39]. Obatoclax has been used in a phase 1 clinical trial on advanced leukemic patients where it showed minimum toxicity and one patient had complete remission for 8 months [44]. We believe obatoclax is a better candidate than ABT-737 and may therefore represent a viable therapeutic option in MB patients. 
TMZ and Lomustine are alkylating agents commonly used in clinic, however, the DNA damage cause by these drugs can be repaired by MGMT [31]. Notably only the $\mathrm{IC}_{50}$ concentration in the MGMT negative cell lines (MED1) was below the maximum tolerated dose of TMZ used in clinical trial [79]. Two novel imidazotetrazine analogues N-3 sulfoxide and N-3 propargyl TMZ derivatives used in this project were developed by Pharminox in order to overcome direct DNA repair by MGMT [31]. It is hypothesised that propargyl and sulfoxide analogues deliver cytotoxic lesions to O6-guanine which cannot be removed by MGMT and both analogues have been shown to cause double DNA strand breaks leading to death in glioma cells. Overcoming MGMT resistance in MB may be reliant on MB tumours being proficient in mismatch repair. This is potentially not an issue since MMR proficiency was recently demonstrated in 74/74 primary MB tumours in a study by von Bueren et al. [33]. In addition to MGMT repair of O6-methylguanine, TMZ methylation at N7methylguanine and N3- methyladenine purines can also be repaired by PARP through BER. Our data demonstrate that sulfoxide and propargyl analogues are cytotoxic to all $4 \mathrm{MB}$ cell lines regardless of MGMT expression and that, unlike TMZ, the efficacy of the propargyl analogue cannot be potentiated by the PARP inhibitor rucaparib. This suggests that putative propargyl modification at $N 3$ and $N 7$ positions may not be recognized by PARP, or cannot be repaired by BER. Stability studies of the 2 analogues have shown that N3-propargyl is more stable than TMZ in plasma (100 minutes versus 30 minutes respectively); however, the N3-sulfoxide analogue is extremely unstable in plasma and hence unsuitable as a clinical candidate. Hence, propargyl could be a good substitute for TMZ in recurrent and progressive MBs and may also be effective in primary tumours.

\section{Conclusions}

We have tested three mechanisms of resistance to chemotherapy mediated by ABCB1, MGMT and antiapoptotic BCL2 family members in MB cell lines. Targeting these factors either by using an ABCB1inhibitor (vardenafil), a novel agent that can circumvent DNA repair (N3-propargyl analogue of TMZ) or a BH3 mimetic to inhibit BCL2 anti-apoptotic proteins (obatoclax) could all be viable therapeutic routes in this malignant tumour in children. Our study of a small subset of MB cell lines, however, indicates that these resistance mechanisms are not mutually exclusive. Hence, the next stage should not only be to test the efficacy of these agents in in vivo models but also to use them in combination. We believe that such an approach will help to redefine $\mathrm{MB}$ as a more chemo-sensitive disease.

\section{Additional files}

Additional file 1: Table S1. Clinicopathological characteristic of MB patients included in Nottingham TMA.

Additional file 2: Table S2. Antibodies used in the $\mathrm{IHC}$ analysis. Additional file 3: Table S3. Correlation of ABCB1 expression with clinicopathological characteristics of DKFZ + Nottingham TMA cohorts.

Additional file 4: Table S4. Clinical characteristics of the 5 patients from whom 6 new MB cell lines were derive.

Additional file 5: Figure S1. Patterns of MB marker subtype immunostaining on each patient's original tissue sample.

Additional file 6: Figure S2. Molecular sub-classification of the 8 MB cell lines.

Additional file 7: Figure S3. Elevated MYCC and MYCN copy numbers in MB cell lines.

Additional file 8: Figure S4. $\beta$-catenin (CTNNB1) sequencing in MED5R and MED6 tumours and cell lines.

Additional file 9: Figure S5. $A B C B 1$ expression in original patient tumours.

Additional file 10: Figure S6. MED1 cells show high ABCB1 protein expression.

Additional file 11: Figure S7. $A B C B 1$ expression is found in a small subpopulation of cells.

Additional file 12: Figure S8. MGMT expression in the original patient tumours.

Additional file 13: Figure S9. Chemosensitization of $T M Z$ and propargyl by rucaparib in MB cell lines.

\section{Abbreviations}

MB: Medulloblastoma; MGMT: O6-methylguanine-DNA-methyltransferase; TMZ: Temozolomide; ABC: ATP-binding cassette; ABCB1: ATP-Binding Cassette, Sub-Family B (MDR/TAP), Member 1, P-glycoprotein or MDR1; MMR: Mismatch repair; PARP: Poly ADP ribose polymerase; BER: Base excision repair; BCL2: B-cell lymphoma/leukaemia 2; BH3: BCL2 homology 3; HEK: Human embryonic kidney cell line; IHC: Immunohistochemistry; FACS: Fluorescent activated cell sorting; Ab: Antibody; Rh123: Rhodamine 123; VPL: Verapamil; SEM: Standard error of the mean; QPCR: Quantitative polymerase chain reaction; OS: Overall survival; PFS: Progression free survival; SDS PAGE: Sodium dodecyl sulfate poly-acrylamide gel electrophoresis.

\section{Competing interests}

The authors declare that they have no competing interests.

\section{Authors' contributions}

RTO was involved in designing the project, performing the majority of experiments, interpreting and analysing the data, statistical analysis and manuscript preparation. IK performed the BCL2 family experiments, interpreted and analysed this data, carried out the statistical analysis and prepared this data for publication. TDB was involved in conceptualising and interpreting the TMZ data and manuscript preparation. LCDS was involved in supporting $\mathrm{IHC}$ experiments, preparing reagents, analysing and interpreting the data. AK was involved in analysing and interpreting the IHC data. SMP was involved in interpreting the data and critically appraising the manuscript. RGG was involved in provision of clinical samples and critically appraising the manuscript. IDK was involved in conceptualising the project, interpreting the data and preparing the manuscript. BC was involved in conceptualising the project, analysing and interpreting the data and preparing the manuscript. All authors read and approved the final manuscript.

\section{Acknowledgements}

We thank Professor James Lowe for histopathological review of the original patient tumour samples. We thank Dr Anna Grabowska for her helpful comments and discussion. We would also like to thank Pharminox for providing TMZ, Sulfoxide and propargyl and Geminx for obatoclax. This 
study was supported by the Ministry of Higher Education and Scientific Research/Kurdistan Regional Government/lraq.

\section{Author details}

'Children's Brain Tumour Research Centre, Division of Child Health, Obstetrics and Gynaecology, School of Medicine, University of Nottingham, QMC, Nottingham NG7 2UH, UK. ${ }^{2}$ Centre for Biomolecular Sciences, School of Pharmacy, University of Nottingham, Nottingham NG7 2UH, UK. ${ }^{3}$ Clinical Cooperation Unit Neuropathology, German Cancer Research Center (DKFZ), Im Neuenheimer Feld 280, Heidelberg, Germany. ${ }^{4}$ Division of Pediatric Neurooncology, German Cancer Research Center (DKFZ), Im Neuenheimer Feld 580 69120, Heidelberg, Germany. ${ }^{5}$ School of Life Sciences, University of Nottingham, QMC, Nottingham NG7 2UH, UK.

Received: 16 May 2014 Accepted: 17 May 2014

Published: 30 May 2014

\section{References}

1. Pizer BL, Clifford SC (2009) The potential impact of tumour biology on improved clinical practice for medulloblastoma: progress towards biologically driven clinical trials. Br J Neurosurg 23(4):364-375

2. Campen CJ, Dearlove J, Partap S, Murphy P, Gibbs IC, Dahl GV, Fisher PG (2012) Concurrent cyclophosphamide and craniospinal radiotherapy for pediatric high-risk embryonal brain tumors. J Neurooncol 110(2):287-291

3. Lannering B, Rutkowski S, Doz F, Pizer B, Gustafsson G, Navajas A, Massimino M, Reddingius R, Benesch M, Carrie C (2012) Hyperfractionated Versus Conventional Radiotherapy Followed by Chemotherapy in Standard-Risk Medulloblastoma: Results From the Randomized Multicenter HIT-SIOP PNET 4 Trial. J Clin Oncol 30(26):3187-3193

4. Burger PC, Yu I, Tihan T, Friedman HS, Strother DR, Kepner JL, Duffner PK, Kun LE, Perlman EJ (1998) Atypical teratoid/rhabdoid tumor of the central nervous system: a highly malignant tumor of infancy and childhood frequently mistaken for medulloblastoma: a Pediatric Oncology Group study. Am J Surg Pathol 22(9):1083-1092

5. Gottardo NG, Gajjar A (2006) Current therapy for medulloblastoma. Curr Treat Options Neurol 8(4):319-334

6. Taylor RE, Bailey $\mathrm{CC}$, Robinson $\mathrm{KJ}$, Weston $\mathrm{CL}$, Walker DA, Ellison D, Ironside J, Pizer BL, Lashford LS (2005) Outcome for patients with metastatic (M2-3) medulloblastoma treated with SIOP/UKCCSG PNET-3 chemotherapy. Eur J Cancer (Oxford, England: 1990) 41(5):727-734, doi:10.1016/j.ejca.2004.12.017

7. Zeltzer PM, Boyett JM, Finlay JL, Albright AL, Rorke LB, Milstein JM, Allen JC, Stevens KR, Stanley P, Li H (1999) Metastasis stage, adjuvant treatment, and residual tumor are prognostic factors for medulloblastoma in children: conclusions from the Children's Cancer Group 921 randomized phase III study. J Clin Oncol 17(3):832-832

8. Gandola L, Massimino M, Cefalo G, Solero C, Spreafico F, Pecori E, Riva D, Collini P, Pignoli E, Giangaspero F (2009) Hyperfractionated accelerated radiotherapy in the Milan strategy for metastatic medulloblastoma. J Clin Oncol 27(4):566-571

9. Packer RJ, Zhou T, Holmes E, Vezina G, Gajjar A (2013) Survival and secondary tumors in children with medulloblastoma receiving radiotherapy and adjuvant chemotherapy: results of Children's Oncology Group trial A9961. Neuro Oncol 15(1):97-103

10. Taylor RE, Bailey CC, Robinson K, Weston CL, Ellison D, Ironside J, Lucraft H, Gilbertson R, Tait DM, Walker DA (2003) Results of a randomized study of preradiation chemotherapy versus radiotherapy alone for nonmetastatic medulloblastoma: The International Society of Paediatric Oncology/United Kingdom Children's Cancer Study Group PNET-3 Study. J Clin Oncol 21 (8):1581-1591

11. Kortmann RD, Kühl J, Timmermann B, Mittler U, Urban C, Budach V, Richter E, Willich N, Flentje M, Berthold F (2000) Postoperative neoadjuvant chemotherapy before radiotherapy as compared to immediate radiotherapy followed by maintenance chemotherapy in the treatment of medulloblastoma in childhood: results of the German prospective randomized trial HIT'91. Int J Radiat Oncol Biol Phys 46(2):269-279

12. Tarbell NJ, Friedman H, Polkinghorn WR, Yock T, Zhou T, Chen Z, Burger P, Barnes P, Kun L (2013) High-risk medulloblastoma: a Pediatric Oncology Group randomized trial of chemotherapy Before or after radiation therapy (POG 9031). J Clin Oncol 31(23):2936-2941

13. Ribi K, Relly C, Landolt M, Alber F, Boltshauser E, Grotzer M (2005) Outcome of medulloblastoma in children: long-term complications and quality of life. Neuropediatrics 36(6):357-365
14. Hoff K, Hinkes B, Gerber NU, Deinlein F, Mittler U, Urban C, Benesch M, Warmuth-Metz M, Soerensen N, Zwiener I (2009) Long-term outcome and clinical prognostic factors in children with medulloblastoma treated in the prospective randomised multicentre trial HIT '91. Eur J Cancer 45(7):1209-1217

15. Packer RJ, Gajjar A, Vezina G, Rorke-Adams L, Burger PC, Robertson PL, Bayer L, LaFond D, Donahue BR, Marymont MAH (2006) Phase III study of craniospinal radiation therapy followed by adjuvant chemotherapy for newly diagnosed average-risk medulloblastoma. J Clin Oncol 24(25):4202-4208

16. Grundy R, Wilne S, Robinson K, Ironside J, Cox T, Chong W, Michalski A, Campbell R, Bailey C, Thorp N (2010) Primary postoperative chemotherapy without radiotherapy for treatment of brain tumours other than ependymoma in children under 3 years: results of the first UKCCSG/SIOP CNS 9204 trial. Eur J Cancer 46(1):120-133

17. Pizer B, Clifford S (2008) Medulloblastoma: new insights into biology and treatment. Arch Dis Child Educ Pract Ed 93(5):137-144

18. Gajjar A, Chintagumpala M, Ashley D, Kellie S, Kun LE, Merchant TE, Woo S, Wheeler G, Ahern V, Krasin MJ (2006) Risk-adapted craniospinal radiotherapy followed by high-dose chemotherapy and stem-cell rescue in children with newly diagnosed medulloblastoma (St Jude Medulloblastoma-96): long-term results from a prospective, multicentre trial. Lancet Oncol 7(10):813-820

19. Jakacki R, Burger P, Zhou T, Holmes E, Packer R, Goldwein J, Mehta M, Pollack I (2007) Outcome for metastatic (M+) medulloblastoma (MB) treated with carboplatin during craniospinal radiotherapy (CSRT) followed by cyclophosphamide (CPM) and vincristine (VCR): Preliminary results of COG 99701. J Clin Oncol 25(18S):2017

20. Aguilera D, Mazewski C, Fangusaro J, MacDonald TJ, McNall-Knapp RY, Hayes LL, Kim S, Castellino RC (2013) Response to bevacizumab, irinotecan, and temozolomide in children with relapsed medulloblastoma: a multi-institutional experience. Childs Nerv Syst 29(4):589-596, doi:10.1007/s00381-012-2013-4

21. Akyüz C, Demir HA, Varan A, Yalçın B, Kutluk T, Büyükpamukçu M (2012) Temozolomide in relapsed pediatric brain tumors: 14 cases from a single center. Childs Nerv Syst 28(1):111-115

22. Padovani L, Andre N, Gentet JC, Figarella Branger D, Scavarda D, Verschuur A, Chinot O, Cowen D, Muracciole X (2011) Reirradiation and concomitant metronomic temozolomide: an efficient combination for local control in medulloblastoma disease? J Pediatr Hematol Oncol 33(8):600

23. Johnsen Jl, Kogner P, Albihn A, Henriksson MA (2009) Embryonal neural tumours and cell death. Apoptosis 14(4):424-438, doi:10.1007/ s10495-009-0325-y

24. Rutkowski S, Bode U, Deinlein F, Ottensmeier H, Warmuth-Metz M, Soerensen N, Graf N, Emser A, Pietsch T, Wolff JEA (2005) Treatment of early childhood medulloblastoma by postoperative chemotherapy alone. N Engl J Med 352(10):978-986

25. Grill J, Sainte-Rose C, Jouvet A, Gentet JC, Lejars O, Frappaz D, Doz F, Rialland X, Pichon F, Bertozzi Al (2005) Treatment of medulloblastoma with postoperative chemotherapy alone: an SFOP prospective trial in young children. Lancet Oncol 6(8):573-580

26. Rutkowski S, Gerber NU, Von Hoff K, Gnekow A, Bode U, Graf N, Berthold F, Henze G, Wolff JEA, Warmuth-Metz M (2009) Treatment of early childhood medulloblastoma by postoperative chemotherapy and deferred radiotherapy. Neuro Oncol 11(2):201-210

27. Szakács G, Paterson JK, Ludwig JA, Booth-Genthe C, Gottesman MM (2006) Targeting multidrug resistance in cancer. Nat Rev Drug Discov 5(3):219-234

28. Chou PM, Reyes-Mugica M, Barquin N, Yasuda T, Tan X, Tomita T (1995) Multidrug resistance gene expression in childhood medulloblastoma: correlation with clinical outcome and DNA ploidy in 29 patients. Pediatr Neurosurg 23(6):283-292

29. von Bossanyi P, Diete S, Dietzmann K, Warich-Kirches M, Kirches E (1997) Immunohistochemical expression of P-glycoprotein and glutathione S-transferases in cerebral gliomas and response to chemotherapy. Acta Neuropathol 94(6):605-611

30. Hussein D, Punjaruk W, Storer LCD, Shaw L, Ottoman R, Peet A, Miller S, Bandopadhyay G, Heath R, Kumari R (2011) Pediatric brain tumor cancer stem cells: cell cycle dynamics, DNA repair, and etoposide extrusion. Neuro Oncol 13(1):70-83

31. Zhang J, Stevens M, Bradshaw T (2012) Temozolomide: mechanisms of action, repair and resistance. Curr Mol Pharmacol 5(1):102

32. Faoro D, von Bueren AO, Shalaby T, Sciuscio D, Hürlimann ML, Arnold L, Gerber NU, Haybaeck J, Mittelbronn M, Rutkowski S (2011) Expression of O 
6-methylguanine-DNA methyltransferase in childhood medulloblastoma. J Neurooncol 103(1):59-69

33. von Bueren AO, Bacolod MD, Hagel C, Heinimann K, Fedier A, Kordes U, Pietsch T, Koster J, Grotzer MA, Friedman HS, Marra G, Kool M, Rutkowski S (2012) Mismatch repair deficiency: a temozolomide resistance factor in medulloblastoma cell lines that is uncommon in primary medulloblastoma tumours. Br J Cancer 107(8):1399-1408, doi:10.1038/bjc.2012.403

34. Tisdale MJ (1987) Antitumour imidazotetrazines-XV: Role of quanine O6 alkylation in the mechanism of cytotoxicity of imidazotetrazinones. Biochem Pharmacol 36(4):457-462

35. Daniel R, Rozanska A, Mulligan E, Drew Y, Thomas H, Castelbuono D, Hostomsky Z, Plummer E, Tweddle D, Boddy A (2010) Central nervous system penetration and enhancement of temozolomide activity in childhood medulloblastoma models by poly (ADP-ribose) polymerase inhibitor AG-014699. Br J Cancer 103(10):1588-1596

36. Curtin NJ, Wang LZ, Yiakouvaki A, Kyle S, Arris CA, Canan-Koch S, Webber SE, Durkacz BW, Calvert HA, Hostomsky Z (2004) Novel poly (ADP-ribose) polymerase-1 inhibitor, AG14361, restores sensitivity to temozolomide in mismatch repair-deficient cells. Clin Cancer Res 10(3):881-889

37. Zhang J, Stevens MF, Hummersone M, Madhusudan S, Laughton CA, Bradshaw TD (2011) Certain imidazotetrazines escape O6-methylguanineDNA methyltransferase and mismatch repair. Oncology 80(3-4):195-207

38. Vogler M, Dinsdale D, Dyer MJS, Cohen GM (2008) BCl-2 inhibitors: small molecules with a big impact on cancer therapy. Cell Death \& Differentiation 16(3):360-367

39. Cragg MS, Harris C, Strasser A, Scott CL (2009) Unleashing the power of inhibitors of oncogenic kinases through BH3 mimetics. Nat Rev Cancer 9(5):321-326

40. Huang S, Sinicrope FA (2008) BH3 mimetic ABT-737 potentiates TRAlLmediated apoptotic signaling by unsequestering Bim and Bak in human pancreatic cancer cells. Cancer Res 68(8):2944-2951

41. Schüller U, Schober F, Kretzschmar H, Herms J (2004) Bcl-2 expression inversely correlates with tumour cell differentiation in medulloblastoma. Neuropathol Appl Neurobiol 30(5):513-521

42. Pegoraro L, Palumbo A, Erikson J, Falda M, Giovanazzo B, Emanuel BS, Rovera G, Nowell PC, Croce CM (1984) A 14; 18 and an 8; 14 chromosome translocation in a cell line derived from an acute B-cell leukemia. Proc Natl Acad Sci 81(22):7166-7170

43. Oltersdorf T, Elmore SW, Shoemaker AR, Armstrong RC, Augeri DJ, Belli BA, Bruncko M, Deckwerth TL, Dinges J, Hajduk PJ (2005) An inhibitor of BCl-2 family proteins induces regression of solid tumours. Nature 435(7042):677-681

44. Schimmer AD, O'Brien S, Kantarijian H, Brandwein J, Cheson BD, Minden MD, Yee K, Ravandi F, Giles F, Schuh A (2008) A phase I study of the pan bcl-2 family inhibitor obatoclax mesylate in patients with advanced hematologic malignancies. Clin Cancer Res 14(24):8295-8301

45. O'Brien SM, Claxton DF, Crump M, Faderl S, Kipps T, Keating MJ, Viallet J, Cheson BD (2009) Phase I study of obatoclax mesylate (GX15-070), a small molecule pan-Bcl-2 family antagonist, in patients with advanced chronic lymphocytic leukemia. Blood 113(2):299-305

46. Levesley J, Lusher ME, Lindsey JC, Clifford SC, Grundy R, Coyle B (2011) RASSF1A and the BH3-only mimetic ABT-737 promote apoptosis in pediatric medulloblastoma cell lines. Neuro Oncol 13(12):1265-1276

47. Vogler M, Dickens D, Dyer MJS, Owen A, Pirmohamed M, Cohen GM (2011) The B-cell lymphoma 2 (BCL2)-inhibitors, ABT-737 and ABT-263, are substrates for P-glycoprotein. Biochem Biophys Res Commun 408(2):344-349

48. Dubuc AM, Remke M, Korshunov A, Northcott PA, Zhan SH, Mendez-Lago M, Kool M, Jones DT, Unterberger A, Morrissy AS, Shih D, Peacock J, Ramaswamy V, Rolider A, Wang X, Witt H, Hielscher T, Hawkins C, Vibhakar R, Croul S, Rutka JT, Weiss WA, Jones SJ, Eberhart CG, Marra MA, Pfister SM, Taylor MD (2013) Aberrant patterns of H3K4 and H3K27 histone lysine methylation occur across subgroups in medulloblastoma. Acta Neuropathol 125(3):373-384, doi:10.1007/s00401-012-1070-9

49. Kool M, Korshunov A, Remke M, Jones DT, Schlanstein M, Northcott PA, Cho YJ, Koster J, Schouten-van Meeteren A, van Vuurden D, Clifford SC, Pietsch T, von Bueren AO, Rutkowski S, McCabe M, Collins VP, Backlund ML, Haberler C, Bourdeaut F, Delattre O, Doz F, Ellison DW, Gilbertson RJ, Pomeroy SL, Taylor MD, Lichter P, Pfister SM (2012) Molecular subgroups of medulloblastoma: an international meta-analysis of transcriptome, genetic aberrations, and clinical data of WNT, SHH, Group 3, and Group 4 medulloblastomas. Acta Neuropathol 123(4):473-484, doi:10.1007/s00401-012-0958-8

50. Schwalbe EC, Lindsey JC, Straughton D, Hogg TL, Cole M, Megahed H, Ryan SL, Lusher ME, Taylor MD, Gilbertson RJ (2011) Rapid diagnosis of medulloblastoma molecular subgroups. Clin Cancer Res 17(7):1883-1894
51. Ellison DW, Dalton J, Kocak M, Nicholson SL, Fraga C, Neale G, Kenney AM, Brat DJ, Perry A, Yong WH (2011) Medulloblastoma: clinicopathological correlates of SHH, WNT, and non-SHH/WNT molecular subgroups. Acta Neuropathol 121(3):381-396

52. Keles GE, Berger MS, Srinivasan J, Kolstoe DD, Bobola MS, Silber JR (1995) Establishment and characterization of four human medulloblastoma-derived cell lines. Oncol Res 7(10-11):493

53. Ridley L, Rahman R, Brundler MA, Ellison D, Lowe J, Robson K, Prebble E, Luckett I, Gilbertson RJ, Parkes S (2008) Multifactorial analysis of predictors of outcome in pediatric intracranial ependymoma. Neuro Oncol 10(5):675-689

54. Kumar D, Devaraj H (2012) Expression of Wnt 3a, $\beta$-Catenin, Cyclin D1 and PCNA in Mouse Dentate Gyrus Subgranular Zone (SGZ): a Possible Role of Wnt Pathway in SGZ Neural Stem Cell Proliferation. Folia Biol (Praha) 58:115-120

55. Zhao X, Liu Z, Yu L, Zhang Y, Baxter P, Voicu H, Gurusiddappa S, Luan J, Su JM, Leung H-CE (2012) Global gene expression profiling confirms the molecular fidelity of primary tumor-based orthotopic xenograft mouse models of medulloblastoma. Neuro Oncol 14(5):574-583

56. Valera ET, Scrideli CA, Queiroz R, Mori B, Tone LG (2004) Multiple drug resistance protein (MDR-1), multidrug resistance-related protein (MRP) and lung resistance protein (LRP) gene expression in childhood acute lymphoblastic leukemia. Sao Paulo Med J 122(4):166-171

57. Pfaffl MW (2001) A new mathematical model for relative quantification in real-time RT-PCR. Nucleic Acids Res 29(9):e45-e45

58. Barrow J, Adamowicz-Brice M, Cartmill M, MacArthur D, Lowe J, Robson K, Brundler M-A, Walker DA, Coyle B, Grundy R (2011) Homozygous loss of ADAM3A revealed by genome-wide analysis of pediatric high-grade glioma and diffuse intrinsic pontine gliomas. Neuro Oncol 13(2):212-222

59. Ryan SL, Schwalbe EC, Cole M, Lu Y, Lusher ME, Megahed H, OToole K, Nicholson SL, Bognar L, Garami M, Hauser P, Korshunov A, Pfister SM, Williamson D, Taylor RE, Ellison DW, Bailey S, Clifford SC (2012) MYC family amplification and clinical risk-factors interact to predict an extremely poor prognosis in childhood medulloblastoma. Acta Neuropathol 123(4):501-513, doi:10.1007/s00401-011-0923-y

60. Northcott PA, Korshunov A, Witt H, Hielscher T, Eberhart CG, Mack S, Bouffet E, Clifford SC, Hawkins CE, French P (2011) Medulloblastoma comprises four distinct molecular variants. J Clin Oncol 29(11):1408-1414

61. Remke M, Hielscher T, Korshunov A, Northcott PA, Bender S, Kool M, Westermann F, Benner A, Cin H, Ryzhova M (2011) FSTL5 is a marker of poor prognosis in non-WNT/non-SHH medulloblastoma. J Clin Oncol 29 (29):3852-3861

62. Pambid MR, Berns R, Adomat HH, Hu K, Triscott J, Maurer N, Zisman N, Ramaswamy V, Hawkins CE, Taylor MD (2014) Overcoming resistance to sonic hedgehog inhibition by targeting p90 ribosomal 56 kinase in pediatric medulloblastoma. Pediatr Blood Cancer 61(1):107-115

63. Moitra K, Lou H, Dean M (2011) Multidrug efflux pumps and cancer stem cells: insights into multidrug resistance and therapeutic development. Basic Clin Pharmacol Toxicol 89(4):491-502

64. Radice P, Bunn P Jr, Ihde D (1979) Therapeutic trials with VP-16-213 and VM-26: active agents in small cell lung cancer, non-Hodgkin's lymphomas, and other malignancies. Cancer Treat Rep 63(8):1231-1239

65. Ozols RF, Cunnion RE, Klecker RW Jr, Hamilton TC, Ostchega Y, Parrillo JE, Young RC (1987) Verapamil and adriamycin in the treatment of drug-resistant ovarian cancer patients. J Clin Oncol 5(4):641-647

66. Deibert P, SCHUMACHER YO, Ruecker G, Opitz O, Blum H, Rössle M, Kreisel W (2006) Effect of vardenafil, an inhibitor of phosphodiesterase-5, on portal haemodynamics in normal and cirrhotic liver-results of a pilot study. Aliment Pharmacol Ther 23(1):121-128

67. Wardle AJ, Tulloh RM (2013) Paediatric pulmonary hypertension and sildenafil: current practice and controversies. Arch Dis Child Educ Pract Ed 98(4):141-147, doi:10.1136/archdischild-2013-303981

68. Hu J, Ljubimova JY, Inoue S, Konda B, Patil R, Ding H, Espinoza A, Wawrowsky KA, Patil C, Ljubimov AV (2010) Phosphodiesterase type 5 inhibitors increase Herceptin transport and treatment efficacy in mouse metastatic brain tumor models. PLoS One 5(4):e10108

69. Ding PR, Tiwari AK, Ohnuma S, Lee JWKK, An X, Dai CL, Lu QS, Singh S, Yang DH, Talele TT (2011) The phosphodiesterase-5 inhibitor vardenafil is a potent inhibitor of ABCB1/P-glycoprotein transporter. PLoS One 6(4):e19329

70. Gandhi L, Camidge DR, de Oliveira MR, Bonomi P, Gandara D, Khaira D, Hann CL, McKeegan EM, Litvinovich E, Hemken PM (2011) Phase I study of 
Navitoclax (ABT-263), a novel Bcl-2 family inhibitor, in patients with small-cell lung cancer and other solid tumors. J Clin Oncol 29(7):909-916

71. Tahir SK, Yang X, Anderson MG, Morgan-Lappe SE, Sarthy AV, Chen J, Warner RB, Ng SC, Fesik SW, Elmore SW (2007) Influence of BCl-2 family members on the cellular response of small-cell lung cancer cell lines to ABT-737. Cancer Res 67(3):1176-1183

72. Certo M, Del Gaizo MV, Nishino M, Wei G, Korsmeyer S, Armstrong SA, Letai A (2006) Mitochondria primed by death signals determine cellular addiction to antiapoptotic BCL-2 family members. Cancer Cell 9(5):351-365

73. Hann CL, Daniel VC, Sugar EA, Dobromilskaya I, Murphy SC, Cope L, Lin X, Hierman JS, Wilburn DL, Watkins DN (2008) Therapeutic efficacy of ABT-737, a selective inhibitor of BCL-2, in small cell lung cancer. Cancer Res 68 (7):2321-2328

74. Yecies D, Carlson NE, Deng J, Letai A (2010) Acquired resistance to ABT-737 in lymphoma cells that up-regulate MCL-1 and BFL-1. Blood 115(16):3304-3313

75. Vogler M, Butterworth M, Majid A, Walewska RJ, Sun XM, Dyer MJS, Cohen GM (2009) Concurrent up-regulation of BCL-XL and BCL2A1 induces approximately 1000-fold resistance to ABT-737 in chronic lymphocytic leukemia. Blood 113(18):4403-4413

76. Xu H, Krystal GW (2010) Actinomycin D decreases Mcl-1 expression and acts synergistically with ABT-737 against small cell lung cancer cell lines. Clin Cancer Res 16(17):4392-4400

77. Konopleva M, Contractor R, Tsao T, Samudio I, Ruvolo PP, Kitada S, Deng X, Zhai D, Shi Y-X, Sneed T (2006) Mechanisms of apoptosis sensitivity and resistance to the $\mathrm{BH} 3$ mimetic $\mathrm{ABT}-737$ in acute myeloid leukemia. Cancer Cell 10(5):375-388

78. van Delft MF, Wei AH, Mason KD, Vandenberg CJ, Chen L, Czabotar PE, Willis SN, Scott CL, Day CL, Cory S (2006) The BH3 mimetic ABT-737 targets selective $\mathrm{BCl}-2$ proteins and efficiently induces apoptosis via Bak/Bax if MCl-1 is neutralized. Cancer Cell 10(5):389-399

79. Hammond LA, Eckardt JR, Baker SD, Eckhardt SG, Dugan M, Forral K, Reidenberg P, Statkevich P, Weiss GR, Rinaldi DA (1999) Phase I and pharmacokinetic study of temozolomide on a daily-for-5-days schedule in patients with advanced solid malignancies. J Clin Oncol 17(8):2604-2604

doi:10.1186/2051-5960-2-57

Cite this article as: Othman et al.: Overcoming multiple drug resistance mechanisms in medulloblastoma. Acta Neuropathologica Communications 2014 2:57.

\section{Submit your next manuscript to BioMed Central and take full advantage of:}

- Convenient online submission

- Thorough peer review

- No space constraints or color figure charges

- Immediate publication on acceptance

- Inclusion in PubMed, CAS, Scopus and Google Scholar

- Research which is freely available for redistribution 